\title{
EFFECT OF RHODEXIN ON ISOLATED HEART OF GUINEA-PIG
}

\author{
MOTOO IIDA \\ Depariment of Pharmacology, Faculty of Medicine, Tohoku University, Sendai \\ Received for publication November 15, 1954
}

The author has previously examined the effects of the new glycosides rhodexin A and $\mathbf{B}$ found in the leaves and the rhizome of Omoto or Rhodea jabonica on isolated hearts of frogs and found that both show cardiac effect, which is similar to that of digitoxin. Then, I tried to follow up their effect on the mammalian hearts and using isolated hearts of guinea-pigs and rabbits as material, have studied the effects of rhodexin on them and the influence of $\mathrm{CaCl}_{2}$ and $\mathrm{KCl}$ on its effect on the heart, as reported in the following.

\section{METHODS}

Healthy guinea-pigs of about $400 \mathrm{~g}$ and rabbits of about $2 \mathrm{~kg}$ body weight each were selected, the hearts were isolated and connected inseries with a Langendorff-Gunn apparatus, and perfused with Locke's solution saturated with oxygen and warmed to $38 \mathrm{C}$ under a pressure of $60-70 \mathrm{~mm} \mathrm{Hg}$. The heart's pulsation was recorded on the drum and the consumption of Locke's solution during the coronary perfusion through a tambour. Waiting for the pulsation to stabilize, the solution of the drugs were switched in and the effect examined. In the winter season when these experiments were carried out, there was fear to obstruct the coronary circulation by the bubbles which were generated in abundance during the necessary heating to keep the temperature or the solution constant, so that a side tube was attached to the in-put tube just before it enters the tested heart, to shunt off any bubble before it enters the heart.

Rhodexin A and B were obtained from Takeda Pharmacy, as in the previously reported study. The samples were dissolved in propylene glycol and diluted with normal Locke's solution for use.

\section{RESULTS}

The pulsation of a guinea-pig's heart improves much immediately upon its connection with the perfusion apparatus, growing in amplitude and its rate counting about 180 per minute, but later falls rather sharply both in amplitude and rate. In about 10 minutes, the pulsation again begin to recover slowly in amplitude and the rate becomes steady, keeping such a state of stability rather for a long while. Thereafter, the amplitude begins to redecrease, the ratc becomes irregular or lowered about one hour alter the commencement of the experiment and the ventricular move- 
ment comes to a standstill in one and a half or two hours. The consumption of the solution for coronary perfusion is large at the time when the amplitude and pulse rate both increases and is less at the time of thc decrease of pulsation, but such changes are less marked than the changes in the pulsation and also lag in time behind the latter changes.

The drug solutions were administered about 20 minutes after the beginning of the perfusion, when the rhythm became stable. Since cases of abnormally slack rhythm or slow perfusion showed very low sensitivity to drugs, such cases were omitted from the tests.

I. Effects of rhodexin $A$ and $B$ in single abslicalion: With $0.00001 \%$ solution of rhodexin A, some cases showed no reaction, and some slight gain in amplitude and pulsation rate in 30-40 minutes and rise in tension with the lapse of time till the ventricle stopped in systole.

With $0.00002 \%$ solution of the same, the amplitude gradually increased, together with a slight increase in the coronary circulation, in $20-30 \mathrm{~min}$, followed by irregularity in pulsation rate and rapid rise of tension resulting in systolic stoppage of the ventricle.

With $0.00005 \%$ solution, marked increase of amplitude and rhythm occurred within several minutes, followed by irregularity in pulse rate and often an increase of the amplitude to twice that before the application of the drug. Then, the tension rises entailing reduction of amplitude and finally the systolic arrest of the ventricle.

With $0.0001 \%$ solution, the effect is similar with that of the preceding, rapidly followed by irregular rhythm while the amplitude increases to twice or thrice that before the application. Then the pulsation steeply falls in frequency, the tension rises and the stoppage of the ventricle follows. In any case, the atrium and the sinus keep

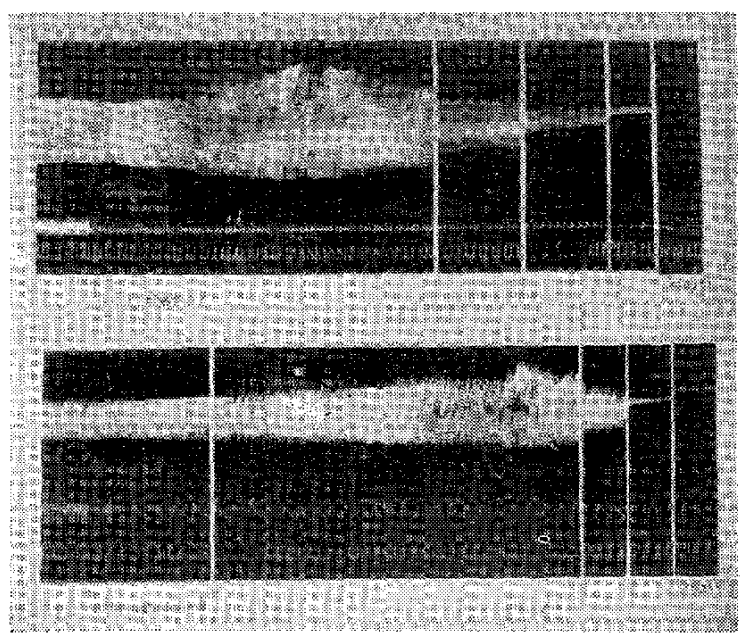

FIG. 1. Effect of rhodexin on isoluced heart of guinea-pig. Upper: Effect of $0.0001 \%$ rhodexin A used singly. Lower: Effect of $0.0001 \%$ rhodexin B used singly. 
on pulsating after the stoppage of the ventricle, and the perfusion goes on too, though it decreases in quantity.

With $0.00001 \%$ rhodexin B, little, if any, effect is observable. With $0.00002 \%$ solution thereof, some cases show no effect, but some cases show slight rise in amplitude and rhythm in 30-40 min, followed by gradual abatement of the amplitude and rise of tension, resulting in the stoppage of the ventricle. With $0.00005 \%$ solution, the amplitude and the rhythm rises visibly in $10-15 \mathrm{~min}$, after the application, followed by irregular rhythm and a rise in tension, entailing stoppage of the ventricle. With $0.0001 \%$ solutian, the amplitude and the rhythm immediately rise after the application, promptly succeeded by irregular rhythm while the amplitude rises to over twice that prior to the application, then by a rise in tension and diminution of the amplitude, leading to the stoppage of the ventricle.

Next, as control tests, I have subjected digitoxin to similar examination.

With $0.00001 \%$ solution of digitoxin, the amplitude and the rhythm rose slightly in 20-30 min, followed by gradual rise in tension and diminution of amplitude, and finally by the ventricular arrest. With $0.00002 \%$ solution, the amplitude rises soon after the application, the pulse rate increasing simultaneously, then the tension rises with decrease in the amplitude, leading to the ventricular standstill. With $0.00005 \%$ solution, the amplitude and the rhythm rise immediately following the application, but at once the rate becomes irregular, and rapidly falls, the tension rises and the amplitude diminishes causing the ventricular arrest.

The effect of $0.0001 \%$ solution of digitoxin is quite similar to that of the $0.00005 \%$ solution above, except that the time to the ventricular arrest is somewhat curtailed here.

In summarizing the above results of rhodexin A and B to isolated hearts of guineapigs, I find them not much different from those when isolated hearts of frogs were used in similar tests. Here also, the effects of rhodexin $A$ and $B$ were similar to that of digitoxin, rhodexin A showing somewhat stronger effect than $B$, but the difference was not so marked as on frog's hearts. The effects of rhodexin A and B on isolated hearts of rabbits were almost the same as on hearts of guinea-pigs detailed above, little difference in sensitivity being shown by the two kinds of mammals. The difference in the effects of rhodexin $A$ and $B$ was also not marked here either. For example, an application of a $0.00002 \%$ soiution of either $\mathrm{A}$ or $\mathrm{B}$, the amplitude and the rhythm gradually and slightly increased, till, about 20-30 min after the application, both the pulse rate and the amplitude begins to diminish, the tension to rise and finally the ventricle was brought to standstill. With $0.0001 \%$ solution of rhodexin A, the pulse rate immediately rose atter the application. While the amplitude rose to more than twice that before, which rises even more in some minutes, the rate falling into irregular beats simultaneously. A diminution both in the amplitude and the rate then follows the tension rises and the pulsation finally stops altogether. With $0.0001 \%$ 
solution of rhodexin $B$, the amplitude and the rhythm increased only gradually, so that the former increased to one and a half the width of that before the application in 2-3 min. Thereafter, the rate became irregular and lower, while the tension gradually rose, finally leading to the ventricular arrest.

II. Influence of $\mathrm{CaCl}_{2}$ and $\mathrm{KCl}$ on the efficacy of rhodexin on isolated heari of guinea pig: It is well known that the efficacy of digitalis is influenced by various external factors, and there are not a few reports on such influences of inorganic electrolytes. Loewi (1), Fischer (2), Tominaga ef al. (3) have reported that Ca increases the effcct of digitalis. Nyiri and Du Bois (4) also have reported that by augmentation of Ca the effect of digitalis is strengthened and speeded up. On the other hand, Konschegg (5), Bülbring (6), Takezaki (7) and Haku (8) have announced that the heart disturbed by perfusion with Ringer's solution defective or short in $\mathrm{Ca}$ can be reinstituted by digitalis. Besides, Schwiegk (9), Junkmann (10), Handovsky (11), Hoffmann (12), Nuki (13) and Umezu (14) have reported on the influence of the change in Ca content on the efficacy of digitalis on the heart.

On the other hand, Takezaki has reported that when the $\mathrm{Ga} / \mathrm{K}$ ratio in the perfusion solution is lowered, that is, the content of $\mathrm{KCl}$ is relatively heightened, the cardiac effect of digitalis is weakened. Nuki also reports that the presence of $\mathrm{K}$ abates. the efficacy of digitalis.

Thus, it is evident that there is a close relation between the effect of digitalis and calcium and potassium contents, so I have tried to examine the influence of $\mathrm{Ca}$ and $\mathrm{K}$ on the cardiac effects of rhodexin similar in action to the digitalis glycosides.

A) Action of $\mathrm{CaCl}_{2}$ and $\mathrm{KCl}$ on isolated hart.

a) Effect of Locke's solution with altered $\mathrm{CaCl}_{2}$ content on isolated hearl of guineapig: It has been established by many past cxperiments that $\mathrm{Ca}$ has an excitant action on isolated hearts. Ringer has ascertained that Ca acts in depressing diastole, fortifying the systole and prolonging the maintenance of systole of isolated frog's hearts, which repeated and confirmed by Loeb (15), Howell (16), Langendorff (17) and many others. Langendorff \& Hueck (18), Rutkewitsch (19) of al. have affirmed the same action of $\mathrm{Ca}$ on isolated mammalian heart. As to the effect of $\mathrm{K}$ on the heart, Martin (20) and Gross (21) have reported that increase of $\mathrm{K}$ in a Locke's solution inhibits the heart action and finally results the veatricular standstill. Sakai 22 ;, Rohm (23) and Zwardemaker (24) rcported that in complete absence of $\mathrm{K}$ from the Locke's solution the frog's hearts shows irregularity and finally stops. The author of this paper has cxperimentally observed the change of effect of normal Locke's solution on isolated hearts of guinea-pigs upon altering the $\mathrm{Ca}$ and $\mathrm{K}$ content in the solution. The composition of the original and altercd Loke's solution is as follows:

1. Normal Locke's solution: $\mathrm{NaCl} 0.9 \%, \mathrm{KCl} 0.042 \%, \mathrm{CaCl}_{2} \cdot 0.024 \%, \mathrm{NaHCO}_{3}$ $0.02 \%$, glucose $0.1 \%$.

2. 2-Ca Locke's solution: With the above $\mathrm{CaCl}_{2}$ content doubled. 
3. 3-Ga Locke's solution: Ditto tripled.

4. 5-Ca Locke's solution: Ditto quintupled.

5. $1 / 2-$ Ca Lock's solution: Ditto halved.

6. Ca-free Locke's solution: Ditto entirely eliminated.

When 2-Ca Locke's solution is applied to an isolated heart of a guinea-pig the heart's pulsation slightly gains strength and increases a little in amplitude. With 3-Ca Locke's solution, the strengthening is more pronounced. With 5-Ca Locke's solution the effect is even much more apparent, the systole being markedly fortified and the diastolc being weakened, but later on the amplitude begins to diminish and the pulse rate to decrease at the same time, keeping up a weakened heart movement for a time till the ventricle comes to a standstill.

With $1 / 2-\mathrm{Ca}$ Locke's solution, the heart contraction weakens and the amplitude narrows down to below $2 / 3$ of the original strength, this state being maintained for a time. Ca-free Locke's solution, the weakening of systole is more marked, the amplitude is extremely reduced after the application, and with the slackening of the pulsc rate, the ventricle comes to stop in diastole. After the stoppage of the ventricle, the atrium and the sinus are always found to maintain their movement for a while.

b) Action of Locke's solution with altered $\mathrm{KCl}$ content on isolated heart of guineapig: The Locke's solution used in the tests were composed as follows:

1. 2-K Locke's solution: With the $\mathrm{KCl}$ content double to that in normal Locke's solution.

2. 3-K Locke's solution: With the $\mathrm{KCl}$ content tripled.

3. 5-K Locke's solution: Ditto quintupled.

4. $1 / 2-\mathrm{K}$ Locke's solution: Ditto halved.

5. K-free Locke's solntion: Ditto cntirely climinated.

When 2-K Locke's solution is applied to an isolated heart of a guinea-pig, instead of normal Lócke's solution, both the amplitude and the pulse rate lowers, finally leading to the stoppage of the ventricle in systolic position. With $3 \cdot \mathrm{K}$ and $5-\mathrm{K}$ Locke's solutions, the effect is more marked, the amplitude and the rate diminishing right upon the application, leading to a prompter stoppage of the ventricle. Even after the stoppage of the ventricle the atrium and the sinus keep on pulsating. When normal Locke's solution is switched in again, the heart recovers from the disturbance due to the added content of $\mathrm{K}$ to normalcy.

When 1/2-K Locke's solution is applied, the amplitude increases slightly, but owing to the disturbance in the conduction, the ventricle is liable to prompt stoppage. With K-free Locke's solution, the heart's action is similarly expedited at first, bringing about a larger amplitude, but the disturbance of conduction also appears forcibly and causes the ventricle to stop abruptly in systolic position.

As detailed above, it is evident that an increase of $\mathrm{Ca}$ or a decrease of $\mathrm{K}$ content in Locke's solution acts in strengthening and stimulating the heart action, while a decrease of $\mathrm{Ca}$ or an increase of $\mathrm{K}$ content acts repressively. 


\section{B) Influence of $C a$ on ths effect of rhstexin in is slated hearl of guinea-pig}

a) Influence of increased Ca content: When an isolated heart of a guinea-pig is pre-treated with 3-Ca Locke's solution and then a $0.00001 \%$ solution of rhodexin A-a dilution showing no efficacy if uscd singly-is applied, the amplitude and the rhythm increases slightly and the stoppage of the ventricle is brought about sooner than in a control test. Now, when $0.00001 \%$ solution of rhodexin $\mathrm{A}$ is applied in combination

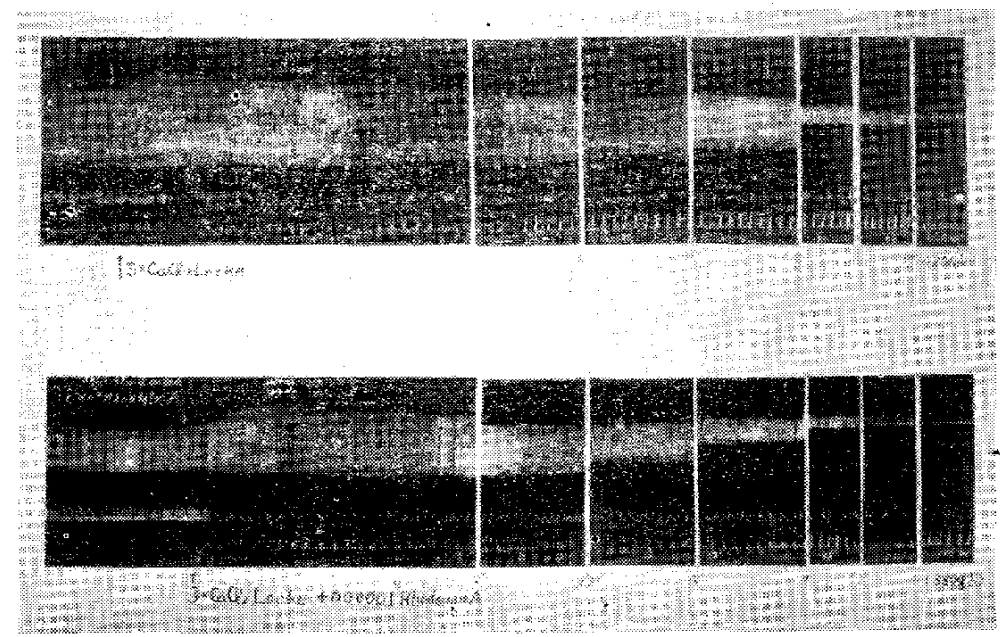

FIG. 2. Influence of $\mathrm{C}_{3}$ on effect of rholexin on is lated heart of guinea-pig.

Upper: 3-Ca Locke's solution used singly.

Lower: $3-\mathrm{Ca}$ Locke's solution plus $0.00001 \%$ rhodexin A.

with 3-Ca Locke's solution the cffect is more tangible than rhodexin alone, the amplitude growing at once upon application, and the tention rising with the increase of the pulse rate, followed by the ventricular arrest. The time to the stoppage of the ventricle is also shortened.

From such results of the experiment, it may be concluded that the effect of rhodexin in raising the amplitude and the tension in the heart is fortified and expedited by the heightening of $\mathrm{Ca}$ content, that is to say, the cardiac action of rhodexin is strengthened thereby.

b) Influence of raducing and eliminating th: $\mathrm{CaCl}_{2}$ content: With 12-Ca Locke's solution above used in combination with $0.00001 \%$ rhodexin A solution, the result is little different from that of simple 1/2-Ca solution, scarcely any effect of rhodexin being observable. When Ca-free Locke's solution is used in similar combination, the effect of rhodexin is again unindicated. When, however, $0.00002 \%$ rhodexin $\mathrm{A}$ is used in the combination, the effect of Ca-free Locke's solution appears first, entailing lowered amplitude and pulse rate, but thereafter the effect of rhodexin overcomes the cardiac disturbance duc to the elimination of $\mathrm{Ca}$ and fortifies the amplitude and the rhythm. Later on with the rise of the tension, the amplitude and the rate drops again, finally leading to a stoppage of the ventricle. 


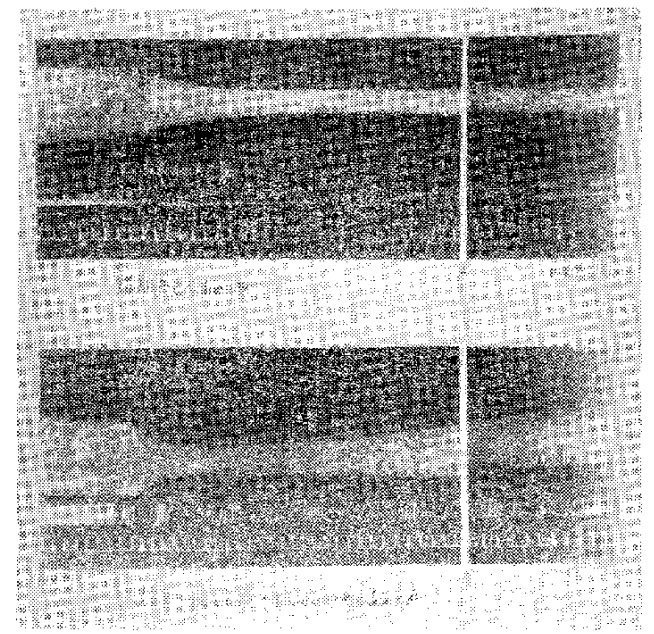

F1G. 3. Influence of Ca of effect of rholexin on isolited heart of guinea-pig.

Upper: With Ca free-Locke's solution,

Lower: With Ca free-Locke's solution plus $0.00002 \%$ rhodexin A.

From the above, it may be concluded that the efficacy of rhodexin is reduced by a decrease or total climination of $\mathrm{Ca}$ content.

C) Influence of $\mathrm{KCl}$ on the effect of rhodexin on isolated heart of guinea-big

a) Influence of increased $\mathrm{KCl}$ content: When 3-K Locke's solution is used in combination with $0.00001 \%$ rhodexin A solution, only the effect of increased $\mathbf{K}$ content is visible, the amplitude and the pulse rate being reduced, leading to the ventricular arrest. With $0.00002 \%$ rhodexin, the result is similar. When, however, $0.00005 \%$ or

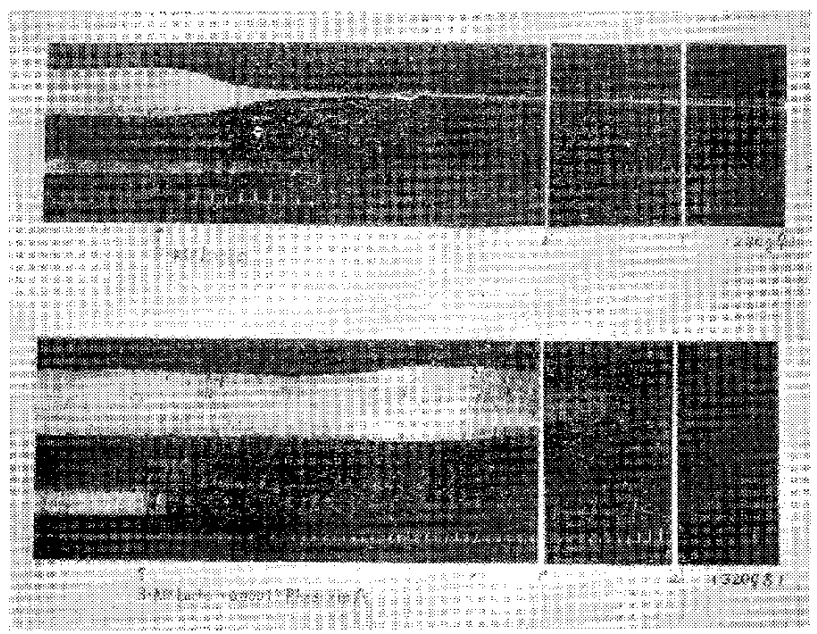

FIG. 4. Influence of $K$ on elfect of rhodexin on isslated heart of guinea-pig.

Upper: 3 K-Locke's solution used singly,

Lowar: $3 \mathrm{~K}$-Locke's solution plus $0.0001 \%$ rhodexin $\mathrm{A}$. 
$0.0001 \%$ rhodexin $\mathrm{A}$ is used in the combination, the effect of $3-\mathrm{K}$ solution in repressing the heart action is controlled by rhodexin, so that the amplitude is not weakened but slightly fortified at first, but soon the pulse rate lowers and the tension riscs, finally leading to the ventricular arrest.

In short, the effect of rhodexin is lowered in comparison with the case when it is applied singly.

From the above, it may be deduced that the effect on the heart of rhodexin is reduced by an increase of $\mathrm{K}$ content.

b) Influnce of lowred $\mathrm{KCl}$ content: When 1/-K Locke's solution is used in combination with $0.00001 \%$ rhodexin $\Lambda$ solution, the amplitude and the rhythm is markedly raised after the application. The result is similar when $\mathrm{K}$-free solution is used in-

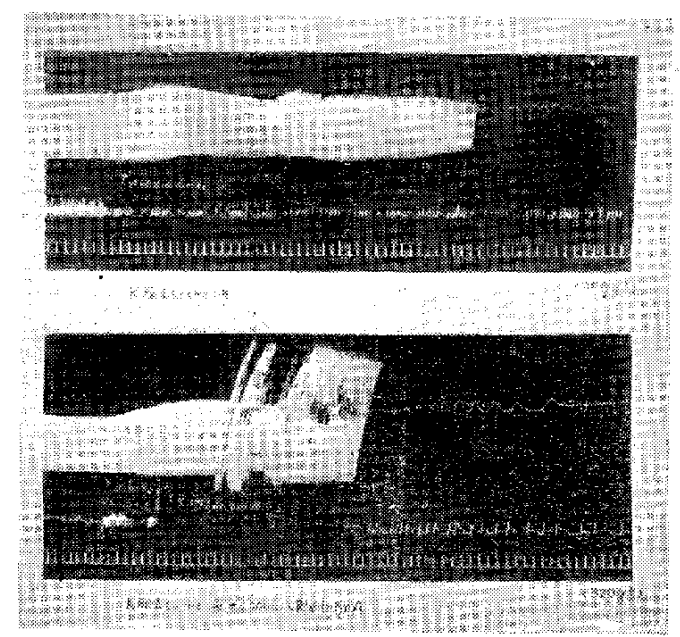

FIG. 5. Influence of $K$ on effect of rhodexin on isolated heart of guinea-pig.

Upper: With $\mathrm{K}$ free-Jocke's solution,

Lower: With $\mathrm{K}$ free-Locke's solution plus $0.00001 \%$ rhodexin $\mathrm{A}$.

stead of the former, the amplitude rising to more than twice that in control test with $\mathrm{K}$-free Locke's solution only.

From the above it may be deduced that a decrease or elimination of $\mathrm{KCl}$ causes a strengthening of the efficacy of rhodexin in increasing and expediting the amplitude of the heart's pulsation.

\section{SUMMARY}

The author has examined the effects of rhodexin $A$ and $B$ and of digitoxin on isolated hearts of guinea-pigs and rabbits in comparison, and next the influence of calcium and potassium on the effect of rhodexin $\mathrm{A}$ on isolated hearts of guinea-pigs. The results obtained may be summarized as follows.

1) The effects of rhodexin $\mathrm{A}$ and $\mathrm{B}$ on isolated hearts of guinea-pigs are similar to that on frog's hearts, are similar to the effect of digitoxin, and the minimum effec- 
tive concentration was found to be about $0.00001 \%$ with rhodexin $\mathrm{A}$ and about $0.00002 \%$ with B, the difference being smaller than when frog's hearts were used as subject. The effects on isolated hearts of rabbits were little different from those on hearts of guinea-pigs.

2) An increase of $\mathrm{Ca}$ content in Locke's solution cxpedites the cardiac contraction, the amplitude and the rhythm being raised. A decrease of $\mathrm{Ca}$ represses the pulsation, cardiac action bccoming weaker, and a total elimination of $\mathrm{Ca}$ furthers the repressive effect. Next, an increase of $\mathrm{K}$ content in the solution represses the cardiac action, lowering the amplitude and the pulse rate. When $K$ content is lowered or totally eliminated, the heart contraction is expedited, the amplitude and the pulsc rate being increased, but subsequently, a disturbance of conduction is occasioned, leading to abrupt stoppage of the ventricle.

3) With an increase of Ca content, the effect of rhodexin is amplified, the strengthening of the amplitude of pulsation and the rise of tension becoming markedly manifest leading to a prompt stoppage of the ventricle. With a decrease or total elimination of Ca content in Locke's solution, the effect of rhodexin used in combination with it is weakened. In short, a change in the Ca content is effective in changing the sensibility of the isolated hearts of guinea-pigs to rhodexin in the same direction.

4) An increase in KCl weakens the cardiac action of rhodexin, while a decrease or total elimination thereof causes a strengthening of the efficacy of rhodexin.

As described above, an increase in $\mathrm{Ca} / \mathrm{K}$ ratio, either as an increase in $\mathrm{CaCl}_{2}$ or decrease or elimination in $\mathrm{KCl}$ content, in Locke's solution have the nearly same effect in fortifying the effect of rhodexin on the heart, while a decrease of $\mathrm{Ca} / \mathrm{K}$ ratio, either in the form of reduced or eliminated $\mathrm{CaCl}_{2}$ or of heightened $\mathrm{KCl}$ content tends to weaken the effect on heart of rhodexin in nearly the same manner.

\section{CONCLUSION}

In the above, I have examined the effect of rhodexin on isolated hearts of guineapigs and the influence of changed $\mathrm{Ca}$ and $\mathrm{K}$ content thereupon, and arrived at the following conclusions:

1. The new glycosides, rhodexin $\mathrm{A}$ and $\mathrm{B}$, show similar cardiac effects on isolated hearts of guinea-pigs similar to digitalis. The effect of rhodexin $A$ is stronger than that of $B$. Their efficacy on hearts of rabbits is not much different.

2. An increase in $\mathrm{Ca}$ content strengthens the efficacy of rhodexin and a decrease or total elimination thereof causes a weakening of the efficacy.

3. An increase of $\mathrm{K}$ content weakens the efficacy of rhodexin and a decrease or total climination thereof strengthens it.

4. Against the disturbance of heart action due to a decrease of $\mathrm{Ca}$ or an increase of $\mathrm{K}$ content, rhodexin, when used in high concentration, acts in antagonism, causing a recovery from such a disturbance to some extent. 


\section{REFERENCES}

1) Loewl, O.:Arch. exfer. Path. u. Pharmakol. 82, 131 (1918)

2) FISCHER, H.: Ibid. 130, 194 (1928)

3) TomiNAGA, I.: Okıyama Igakkai Zasshi (J. Okayama Med. Assoc.)No. 419, 1187 (1924)

4) NYIRI, W. \& DU BOIS, I.: J. Pharmacol. 39, 111 (1980)

5) KonschegG, A, von: Arch. exper. Path. u. Pharmakol. 71, 251 (1913)

6) BúlbRiNG, F.: Ibid. 152, 257 (19:0)

7) TAkFZAKI, T.: Fukuoka Acta Med. 31, 233 (1938)

8) Haku, K.: J. Chosen Med. Assoc. 29, 2307 (1939)

9) SchWIECK, H. : Arch. exper. Path. u. Pharmakol. 162,56 (1931)

10) JUNKMANN, K.: Ibid. 96, 63 (1923)

11) HANDOVSKY, H.: Ibid. 97, 171 (1923)

12) HOFFMANN, H.: Ibid, 96, 105 (192?)

13) NUKI, B : Folia pharmacol, japon. 22, 31 (1936)

14) UMEZU, Z. : Ibid. 33, 233 (1943)

15) LOEB, J.: Pfï̈gers Arch. 80, 299 (1900)

16) Howell, W.: Am. J. Physiol. 2, 47 (1898)

17) LANGENDORFF, O.: Pflügers Arch. 93, 286 (1903)

18) LANGENDORFF, O. UND HUECK, W.: Pfiügers Arch. 96, 473 (1903)

19) RUTKEWITSCH, K.: Ibid. 129, 487 (1909)

20) Martin, E.G.: Am. J. Prysiol. 11, 370 (1904)

21) Gross, E.: Pfiügers Arch. 99, 264 (1903)

22) SAKAI, T.: Z. Biol. 64, 505 (1914)

23) BOEHM, R.: Arch. exper. Path. u. Pharmakol, 75, 230 (1914)

24) ZWaARdemaker, F. H. : Pfï̈gers Arch. 204, 144 (1924) 